\title{
Realizing Social Capital Gain Through Civic Engagement: Lessons for Indonesia's Decentralization
}

\author{
Prama Wiratama ${ }^{1, *}$, Didik Gunawan Suharto ${ }^{2}$, Ismi Dwi Astuti Nurhaeni ${ }^{3}$ \\ ${ }^{1,2,3}$ Universitas Sebelas Maret, Surakarta, Indonesia \\ *Corresponding author.Email: prama.wiratama@student.uns.ac.id
}

\begin{abstract}
This review aims to elaborate on the importance of social capital in handling the COVID-19 pandemic and rise discussion of social capital in the context of Indonesia's decentralization. Based on the recommendations of this review, it is expected that Indonesia's government can accomplish the ideals of decentralization policies. Integrative literature review method applied to 21 related studies. This review concludes that a lot of countries got benefits from social capital while tackling the COVID-19 pandemic. The social capital increases the effectiveness of the government's policy implementation. Important aspects of social capital include trust, volunteerism, and solidarity. These can increase community compliance, help provide the community's basic needs and streamline the implementation of a pandemic management program. The social capital itself can not contribute without good civic engagement. It implies that the government can be benefited from social capital in society through civic engagement. Good long-term civic engagement will increase the social capital account on the public balance sheet. This principle must be applied in post-COVID decentralization policies by realizing social capital gains in society through civic engagement, not utilizing decentralization for personal gains through civic disengagement. This review suggests to Indonesia's government to carry out a mental revolution for public officials in order to foster social capital in society. The government needs to involve communities whose strong social capital to encourage a mental revolution of public officials as well as encourage civic engagement in governance, such as religious communities, volunteers/NGOs, and various communities with various kinds of interests.
\end{abstract}

\section{Keywords: Civic Engagement, Community Engagement, Decentralization, Devolution, Policy} Implementation, Social Capital.

\section{INTRODUCTION}

Countries worldwide have made various efforts to deal with the COVID-19 in terms of medical and nonmedical policies [1]. A number of countries carry out the same policies with different effectiveness of policy implementation [2]-[4]. Referring to the previous research, the effectiveness of crisis management is strongly influenced by the level of social capital in society [5]. Like in accounting, capital gains in the capital market have not become real profits before they are converted into realized capital gains through the sale of shares. Countries with good social capital have not been benefited until it is realized through civic engagement [6].

This study responds to the recommendations of further research given by Pitas and Ehmer (2020) [7] regarding the need for deeper research explaining the importance of social capital in handling the COVID-19 pandemic. This research attempted to answer the following questions: (1) what aspects of social capital are important for fostering civic engagement, (2) how the government uses civic engagement to deal with crises, (3) what communities are targeted by the government to encourage civic engagement, (4) map issues of social capital and civic engagement in handling the pandemic that can be adopted and adapted into Indonesia's decentralization policies. Based on the recommendations of this study, it is expected that the government of Indonesia can accomplish the ideals of decentralization policies.

The integrative literature review method [8], [9] was used in this study. Several previous studies have analyzed the importance of social capital and civic engagement in handling the COVID-19 [5], [6], [10]. However, there are still few articles that synthesize these studies to be contextualized with decentralization policies. The integrative literature review is suitable to enrich 
developed theories or develop new theories. This study is to enrich the theory of social capital that has been developed in the field of health sciences by adding a new perspective of public administration, especially decentralization.

The main source of this study was in the form of scientific articles from academic journals. The search on scholar.google.com was based on relevant keywords such as "social capital", "civic engagement", "COVID-19", "trust", "solidarity", "volunteerism", "community engagement", "public participation", "reciprocity", and "confidence". Although Google Scholar does not separate between scientific articles from scientific journals with articles from private repositories such as Researchgate.net and Academia.edu, it provides more relevant information than other search engines for academic research such as SCOPUS, Taylor \& Francis Online, Wiley Online Library, or SAGE. For the validity and reliability of the information, the authors triangulated data sources by comparing information from various sources of journals. In total, 21 related studies were used in the final analysis.

\section{THEORETICAL REVIEW}

\subsection{Important Aspects Of Social Capital}

In some countries, people do not trust the government and have more trust in their communities. Hence, the government needs to involve communities whose strong trust from their followers to disseminate government policies [10]-[12]. For example, the Muslim community in Somalia takes advantage of their faith in religion and trust in religious leaders as first shields against trauma and stress due to COVID-19. With this belief, they made behavioral adjustments to reduce mobility easily [10].

Trust can grow from a faith or from a political system as in China. Their trust is not in their fellow citizens but more in the political institution, the government. A form of public trust based on authoritarian norms [6]. This kind of trust helps the government to maintain community compliance with the quarantine policy.

On the other hand, there is also trust abuse and is detrimental to the government. Since they trust the community too much, any information that emerges from the community is considered true even though the news is fake. They did not implement social distancing believing that there will be no member to bring the virus into their group, even though the reality can be the opposite [13].

Hong Kong has a different case. There, the people did not trust the government regarding the policy for handling the pandemic. The government did not impose a lockdown and did not encourage the use of masks. This distrust has caused people to practice selfgovernance to handle pandemics based on previous pandemic experiences such as SARS. They voluntarily carried out self-lockdowns and distributed personal protective equipment (PPE) such as face shield and hand sanitizers [14]. As stated by Scheberle (2004), high trust and high involvement can drive the success of policy implementation. However, it was done without government officials' interference. Thus, it can be concluded that trust can have a good or bad effect in handling a pandemic, depending on how it is directed. Trust is also not the only important aspect of social capital in encountering the pandemic.

The success of the Hong Kong community is also influenced by the high level of volunteerism. The capacity of the government bureaucracy to implement policies is limited. The government can collaborate with volunteers to increase the number of workers to expand the program [15]. A patriotic health campaign was carried out by the Chinese government to increase community volunteerism in preventing the spread of the virus [16]. A similar campaign was carried out in Syria to encourage the White Helmets or Syrian Civil Defense to join the "Volunteers against Corona" program to reach the entire region to the most remote areas [17].

Solidarity is an aspect of social capital that can strengthen the bonds of an individual with their communities. Strong solidarity reflects that every member of the community identifies himself as one and the same identity. A hospital in America encourages the solidarity of school children with hospital staff and COVID-19 patients. They were asked to send encouragement cards to the patients and staff at the hospital. This has received positive feedback from both parties. The school was proud to be able to encourage the front-line officers, while staff and patients were deeply moved by the solidarity [18]. Unfortunately, solidarity can also be a source of disaster. For example, the solidarity of a group that trusts false information. This can exacerbate the transmission and death rates caused by COVID-19 [13].

Confidence in institutions is very important for the public in going through a crisis. Different with trust to government which more concern about the trust of people to the credibility of government decision, confident in institutions is more concern about the ability of government to implement the decision. The death rate due to a pandemic are declining along with people's confidence in the country's ability to control the pandemic [13]. Some people confident in the government not because they understand the policy but simply because of the subjective credibility of the source of the information. People who receive information from religious institutions such as pagodas and churches have more confidence in the government's ability to deal with pandemics and the ability of the public to adapt to these policies [19].

Reciprocity is a form of social capital that can provide a provision for society to go through a crisis. Stevenson et al. (2020) [20] concluded that neighbors who, before the crisis, liked giving help, during the crisis, would also help their neighbors. This mutual 
assistance has a significant effect on community compliance with the lockdown policy. Likewise with ethics and norms. The willingness of someone to sacrifice one's personal interests for the sake of the common interest is proven empirically influencing one's obedience to stay at home [6], [21]. Some people think that keeping the safety of the people in their environment is an obligation. People with social capital like this are easy to be invited to reduce mobility and physical contact for the safety of those around them [22], [23].

Subjective well-being also affects the success of handling the pandemic. Subjectively, religious individuals are comfortable with their religious community and are very obedient to religious teachings and community decisions [10], [12]. The community can also be very obedient to the lockdown policy because their hobbies are into it. For example, the urban farming community. They happily stay at home to grow crops all day long. In fact, many urban farmers emerged since the pandemic. Apart from personal well-being, urban farming can also be a solution for the food supplies which have been somewhat disrupted during the pandemic [24].

\subsection{How The Government Utilizes Social Capital}

There are three tasks of the government during a pandemic. They are (1) providing the community basic needs during a crisis, (2) ensuring that the community complies with government policies, (3) implementing pandemic management policies. In terms of policy implementation, the government is unable to carry out its tasks alone. Civic engagement is needed to assist the government in preventing, handling, and recovering from a pandemic.

For instance, a religious community of Orthodox Judaism that was first exposed to the COVID-19 virus in America assisted the government by passing important and valid information to members of its community. In addition, they also provided services and helped provide for the needs of their community members [12]. A collaboration between health authorities and local religious communities provided services via a telephone conference call. Services provided include providing information and consultation on COVID-19, religious services, and distribution of food and masks [11].

In China, local communities are empowered to increase public compliance with movement control policies. Local communities know more about people in the local area making screening more effective [16]. In addition, the involvement of volunteers reduced daily transmission rates [15]. The attachment of individuals to the community encouraged them to comply with policies established by the government such as stay-at-home policies [25].

Some communities are proactively helping to implement pandemic management policies. For example, the indigenous people of Australia, the
Aborigines, respond quickly to COVID-19 by limiting access and translating information from the government to their local language [26]. The Syrian diaspora in cooperation with the Syrian government updated their health system based on the latest information obtained from all over the world, particularly from the United Kingdom and France [17]. In England, the local community played an active role through volunteering in various tasks such as vaccination. About $21 \%$ of the population did this formally and $47 \%$ informally during the onset of the pandemic. Many communities actively offered assistance to communities, supported by local government and other organizations [27].

\subsection{Target Communities}

The neighborhood has the most social capital aspects, such as trust, volunteerism [6], solidarity [18], confidence in institutions [6], reciprocity [20] as well as ethics and norms [21]. Religious communities have the main advantage in the level of trust and confidence in the government [10]-[12], [19]. Volunteer organizations [15]-[17] are very useful if they can bring them in. Volunteer organizations are usually characterized by high skills and qualified experience. In addition, their solidarity is so strong and is easy to mobilize. The governments of China and South Korea are greatly helped by the presence of these volunteers [15], [28].

A family is traditionally a group with a high level of social capital, especially in the aspect of solidarity [7], [19], [25]. Indigenous people [26] and diaspora [17] are communities with members who have the same high social and cultural backgrounds. This led to their strong solidarity. A community of interest [24] has a strength in the subjective well-being of its members. They complied with the stay-at-home policy happily because it is appropriate for their hobby.

\subsection{Lessons for Indonesia's Decentralization}

Decentralization in Indonesia emerged as an effort to democratize government management in the administrative and fiscal fields [29]. This democratization is in the form of civic engagement in determining development priorities and budget utilization. However, in reality, decentralization has not fully driven civic engagement. For example, there are project decisions that did not involve the public [30] and the corrupted funds for fiscal decentralization due to low public transparency [31].

Based on the experience of handling COVID-19, it is clear that civic engagement is important for the successful implementation of government policies. Civic engagement can happen when there is social capital. Public trust, confidence in institutions, volunteerism, and solidarity within the community need to be fostered making them willing to participate in government management programs. The government needs to approach various communities to capture various 
interests in the policy formulation process. However, it is not an easy matter.

The challenge lies in the mentality of public officials. Indonesia has long adopted the Old Public Administration (OPA) system under Suharto's leadership. It was in 1998 until now that Indonesia has experienced democratic reform towards the New Public Service (NPS) paradigm [32]. There are still public officials in the OPA generation who are on duty today. They impact the mentality of the new public officials. Changing the paradigm of "being served" into "serving" is not easy. Shifting the paradigm of corruption, collusion, and nepotism to transparency and public accountability requires a long time. The tagline "if it can be difficult, why make it easier?" requires a fundamental cultural change to be replaced with "if it is easy, why makes it difficult?". Moreover, the community mentality is still attached to the OPA model of bureaucratic system that they prefer to believe in insiders rather than follow the prevailing system.

It needs more field research about how to foster social capital in Indonesia. In authors opinion, it takes the right mentality from public officials to foster public confidence with openness, transparency, and public accountability. It can be in the form of good cooperation with the community to foster volunteerism. Solidarity will only emerge when public officials are willing to step in directly to solve public problems, not only seeing the suffering of the people from the top of a lighthouse. Confidence in institutions will grow when the public truly feels the good impact of government policies. As long as these things have not been done, it will be difficult for social capital to grow in society. This results in low civic engagement. Meanwhile, the low level of civic engagement will increase the probability of public officials doing power abuse.

Consequently, it is obligatory for the government to carry out a mental revolution for public officials in order to foster social capital in society. The government needs to involve communities whose strong social capital to encourage a mental revolution of public officials as well as encourage civic engagement in governance, such as religious communities, volunteers/NGOs, a community of interest, neighborhood, and various communities with various kinds of interests. Decentralization should not be used to benefit a few parties by eliminating civic engagement. For further research, it needs more field research about fostering social capital of society in different local areas and different political system countries to make a comprehensive comparative study for generalization of social capital theory.

\section{CONCLUSION}

Important aspects of social capital include trust, volunteerism, and solidarity. These have been proven to help the government to increase community compliance, help provide the community's basic needs and streamline the implementation of a pandemic management program through civic engagement. Target communities include neighborhoods, volunteer organizations, and religious communities used by the government to foster civic engagement.

The point that should be internalized to the citizen is that social capital is agnostic, it can have a good or bad impact on policy implementation depending on how it is utilized. Good long-term civic engagement will increase "the social capital account on the public balance sheet". This principle must be applied in Indonesia's decentralization policy. Decentralization should not use to benefit certain parties by taking advantage of the loss of civic engagement.

\section{AUTHORS' CONTRIBUTIONS}

Prama Wiratama contribute in concept od social capital, drafting, and finishing the paper. Didik Gunawan Suharto contribute in guiding the concept of decentralization. Ismi Dwi Astuti Nurhaeni contribute in guiding the concept of civic engagement.

\section{ACKNOWLEDGMENTS}

Authors thank to Lembaga Pengelola Dana Pendidikan (LPDP) for funding the scholarship of first author. Authors also thank to Universitas Sebelas Maret (UNS) for funding the publication of this research.

\section{REFERENCES}

[1] C. Cheng, J. Barceló, A. S. Hartnett, R. Kubinec, and L. Messerschmidt, "COVID-19 Government Response Event Dataset (CoronaNet v.1.0)," Nat. Hum. Behav., vol. 4, no. 7, Art. no. 7, Jul. 2020, doi: 10.1038/s41562-020-0909-7.

[2] S. A. Gómez-Ochoa and O. H. Franco, "COVID19: Facts and Failures, a Tale of Two Worlds," Eur. J. Epidemiol., vol. 35, no. 11, pp. 991-994, Nov. 2020, doi: 10.1007/s10654-020-00692-7.

[3] G. H. T. Ling et al., "Factors Influencing AsiaPacific Countries' Success Level in Curbing COVID-19: A Review Using a Social-Ecological System (SES) Framework," Int. J. Environ. Res. Public. Health, vol. 18, no. 4, Art. no. 4, Jan. 2021, doi: 10.3390/ijerph18041704.

[4] J. H. Liu, "Majority World Successes and European and American Failure to Contain COVID-19: Cultural Collectivism and Global Leadership," Asian J. Soc. Psychol., vol. 24, no. 1, pp. 23-29, 2021, doi: https://doi.org/10.1111/ajsp.12461.

[5] L. R. Varshney and R. Socher, "COVID-19 Growth Rate Decreases with Social Capital," medRxiv, p. 2020.04.23.20077321, Apr. 2020, doi: 10.1101/2020.04.23.20077321. 
[6] C. Wu, "Social capital and COVID-19: a multidimensional and multilevel approach," Chin. Sociol. Rev., vol. 53, no. 1, pp. 27-54, Jan. 2021, doi: $10.1080 / 21620555.2020 .1814139$.

[7] N. Pitas and C. Ehmer, "Social Capital in the Response to COVID-19," Am. J. Health Promot., vol. 34, no. 8, pp. 942-944, Nov. 2020, doi: $10.1177 / 0890117120924531$.

[8] H. Snyder, "Literature Review as a Research Methodology: an Overview and Guidelines," $J$. Bus. Res., vol. 104, pp. 333-339, Nov. 2019, doi: 10.1016/j.jbusres.2019.07.039.

[9] R. J. Torraco, "Writing Integrative Literature Reviews: Guidelines and Examples," Hum. Resour. Dev. Rev., vol. 4, no. 3, pp. 356-367, Sep. 2005, doi: $10.1177 / 1534484305278283$.

[10] J. A. Bentley et al., "Local to global: Somali perspectives on faith, community, and resilience in response to COVID-19," Psychol. Trauma Theory Res. Pract. Policy, vol. 12, no. S1, pp. S261-S263, 2020, doi: 10.1037/tra0000854.

[11] P. Galiatsatos et al., "Community Calls: Lessons and Insights Gained from a Medical-Religious Community Engagement During the COVID-19 Pandemic," J. Relig. Health, vol. 59, no. 5, pp. 2256-2262, Oct. 2020, doi: 10.1007/s10943-02001057-w.

[12] S. L. Weinberger-Litman, L. Litman, Z. Rosen, D. H. Rosmarin, and C. Rosenzweig, "A Look at the First Quarantined Community in the USA: Response of Religious Communal Organizations and Implications for Public Health During the COVID-19 Pandemic," J. Relig. Health, vol. 59, no. 5, pp. 2269-2282, Oct. 2020, doi: 10.1007/s10943-020-01064-x.

[13] F. J. Elgar, A. Stefaniak, and M. J. A. Wohl, "The Trouble with Trust: Time-series Analysis of Social Capital, Income Inequality, and COVID-19 Deaths in 84 Countries," Soc. Sci. Med., vol. 263, p. 113365, Oct. 2020, doi: 10.1016/j.socscimed.2020.113365.

[14] K.-M. Wan, L. Ka-ki Ho, N. W. M. Wong, and A. Chiu, "Fighting COVID-19 in Hong Kong: The Effects of Community and Social Mobilization," World Dev., vol. 134, p. 105055, Oct. 2020, doi: 10.1016/j.worlddev.2020.105055.

[15] Q. Miao, S. Schwarz, and G. Schwarz, "Responding to COVID-19: Community Volunteerism and Coproduction in China," World Dev., vol. 137, p. 105128, Jan. 2021, doi: 10.1016/j.worlddev.2020.105128.

[16] G. Hu and W. Qiu, "From Guidance to Practice: Promoting Risk Communication and Community Engagement for Prevention and Control of Coronavirus Disease (COVID-19) Outbreak in
China," J. Evid.-Based Med., vol. 13, no. 2, pp. 168-172, 2020, doi: https://doi.org/10.1111/jebm.12387.

[17] A. Ekzayez et al., "COVID-19 response in northwest Syria: innovation and community engagement in a complex conflict," J. Public Health, vol. 42, no. 3, pp. 504-509, Aug. 2020, doi: 10.1093/pubmed/fdaa068.

[18] B. Branson, "Cards from the Community: Engagement of the Local Community to Enhance Patient and Staff Experience During the COVID19 Pandemic," Patient Exp. J., vol. 7, no. 2, pp. 156-159, Aug. 2020, doi: 10.35680/23720247.1467 .

[19] B. Xuan Tran et al., "Capacity of local authority and community on epidemic response in Vietnam: Implication for COVID-19 preparedness," Saf. Sci., vol. 130, p. 104867, Oct. 2020, doi: 10.1016/j.ssci.2020.104867.

[20] C. Stevenson, J. Wakefield, J. Drury, and I. Felsner, "Collectively Coping with Coronavirus: Local Community Identification Predicts Giving Support and Lockdown Adherence During the COVID-19 Pandemic.” OSF Preprints, Jul. 20, 2020. doi: 10.31219/osf.io/2uyw7.

[21] W. Ding, R. Levine, C. Lin, and W. Xie, "Social Distancing and Social Capital: Why U.S. Counties Respond Differently to COVID-19," National Bureau of Economic Research, w27393, Jun. 2020. doi: 10.3386/w27393.

[22] F. Borgonovi and E. Andrieu, "Bowling together by bowling alone: Social capital and COVID-19," Soc. Sci. Med., vol. 265, p. 113501, Nov. 2020, doi: 10.1016/j.socscimed.2020.113501.

[23] A. K. Bartscher, S. Seitz, M. Slotwinski, S. Siegloch, and N. Wehrhöfer, "Social Capital and the Spread of Covid-19: Insights from European Countries," Rochester, NY, 2020.

[24] R. Lal, "Home Gardening and Urban Agriculture for Advancing Food and Nutritional Security in Response to the COVID-19 Pandemic," Food Secur., vol. 12, no. 4, pp. 871-876, Aug. 2020, doi: 10.1007/s12571-020-01058-3.

[25] Y. Bian, X. Miao, X. Lu, X. Ma, and X. Guo, "The Emergence of a COVID-19 Related Social Capital: The Case of China," Int. J. Sociol., vol. 50, no. 5, pp. 419-433, Sep. 2020, doi: 10.1080/00207659.2020.1802141.

[26] F. Markham, D. Smith, and F. Morphy, Indigenous Australians and the COVID 19 Crisis: Perspectives on Public Policy. Canberra: Centre for Aboriginal Economic Policy Research, 2020. Accessed: Apr. 05, 2021. [Online]. Available: https://openresearchrepository.anu.edu.au/handle/1885/202733 
[27] H. Maiden, J. Jagroo, P. Shearn, A. Wasielewska, K. Nolan, and N. Bailie, "Spotlight on community engagement: NICE resources in the context of COVID-19-NICE public health guidance update," J. Public Health, no. fdab103, Mar. 2021, doi: 10.1093/pubmed/fdab103.

[28] J. Oh, J.-K. Lee, D. Schwarz, H. L. Ratcliffe, J. F. Markuns, and L. R. Hirschhorn, "National Response to COVID-19 in the Republic of Korea and Lessons Learned for Other Countries," Health Syst. Reform, vol. 6, no. 1, p. e1753464, Dec. 2020, doi: 10.1080/23288604.2020.1753464.

[29] M. Noor, Memahami Desentralisasi Indonesia, Pertama. Yogyakarta: Interpena Yogyakarta, 2012. [Online]. Available: https://portal.fisipunmul.ac.id/site/wpcontent/uploads/2013/02/mnoor_buku_memahami desentralisasi_indonesia\%20(02-02-13-08-4707).pdf

[30] N. Susanto, "Public (Dis)Engagement in Toll Road Project: A Case Study from Indonesia," JKAP J. Kebijak. Dan Adm. Publik, vol. 23, no. 1, Art. no. 1, May 2019, doi: 10.22146/jkap.43994.

[31] Y. Savitri, "Villages in Indonesia Lack Skills to Manage Development Funds," The Jakarta Post, Oct. 03 , 2020 . https://www.thejakartapost.com/news/2020/03/10/ villages-in-indonesia-lack-skills-to-managedevelopment-funds.html (accessed May 03, 2021).

[32] M. Turner, E. Prasojo, and R. Sumarwono, "The Challenge of Reforming Big Bureaucracy in Indonesia," Policy Stud., pp. 1-19, Dec. 2019, doi: 10.1080/01442872.2019.1708301. 